\title{
Editorial
}

\section{Obesity and asthma}

\author{
Obesidade e asma
}

Asma y obesidad

\section{Dirceu Solé 1}

The increasing prevalence of asthma and obesity in many parts of the world, especially in developed and English-speaking countries, has attracted much attention from the scientific community. This fact has motivated initiatives to control the impact of obesity on children's health ${ }^{(1)}$, as well as that of asthma ${ }^{(2)}$. In the last decade, studies in children and adults provided evidence for an association between obesity (defined by body mass index - BMI) and asthma. Excess weight is identified as a risk factor for the development of asthma, decreased asthma control, increased asthma exacerbations, and increased utilization of emergency services; it may also be responsible for the development of future chronic diseases ${ }^{(3)}$. According to some authors, there is evidence that such effects are gender-dependent ${ }^{(4)}$, especially when assessing the impact of obesity on pulmonary function ${ }^{(5)}$. Asthma, because it may facilitate the onset of exercise-induced symptoms, generates inactivity, which, in turn, determines a reduction in physical fitness, leading to the increased triggering of effort-induced symptoms. Recently, a distinct clinical phenotype - obesity-associated severe asthma - has been proposed for some forms of severe asthma that are characterized by being difficult to treat and control ${ }^{(6)}$.

Both asthma and obesity are systemic inflammatory disorders $^{(7)}$. The relationship between them is still a matter of controversy, though. In obesity, hormonal changes associated with increased deposition of adipose tissue may contribute to chronic airway inflammation, which increases the risk of associated morbidities, such as cardiovascular diseases and diabetes. Such inflammation, lodged in the airways, could explain the association with asthma ${ }^{(8)}$. It is believed that inflammatory mediators in adipose tissue, leptin, and low adiponectin levels regulate T-cell proliferation and play an important role in the pathophysiology of pulmonary diseases, also contributing to the aggravation of the systemic inflammation and the uncontrolled production of reactive oxygen species ${ }^{(9)}$. The decrease in antioxidant defenses may worsen the condition, with oxidative stress, and consequent systemic airway inflammation ${ }^{(10)}$. A recent study conducted by our group on obese adolescents with asthma reported increased levels of serum reactive $\mathrm{C}$-protein, without increase of other markers of oxidative stress, when compared to a group of obese adolescents ${ }^{(11)}$.

In this issue of Revista Paulista de Pediatria, Andrade et $a l^{(12)}$ published a study on the association between obesity, determined by BMI, and asthma, considering: age, gender, initial classification, asthma control, and spirometric values (forced expiratory volume in one second [FEV1] and forced expiratory flow between 25 and $75 \%$ of forced vital capacity [FEF25-75\%] at baseline in asthmatic adolescents. A representative sample was evaluated, and no differences were found between genders in relation to the initial classification of asthma or to the level of asthma control. Most patients had persistent asthma, and the disease was partially or completely controlled in more than $85 \%$ of participants. When obese or overweight patients
Instituição: Disciplina de Alergia, Imunologia Clínica e Reumatologia do Departamento de Pediatria da Escola Paulista de Medicina da Universidade Federal de São Paulo (Unifesp), São Paulo, SP, Brasil

TProfessor Titular da Disciplina de Alergia, Imunologia Clínica e Reumatologia do Departamento de Pediatria da Escola Paulista de Medicina da Unifesp, São Paulo, SP, Brasil

\author{
Endereço para correspondência: \\ Dirceu Solé \\ Rua dos Otonis, 725 - Vila Clementino \\ CEP 04025-002 - São Paulo/SP \\ E-mail: sole.dirceu@gmail.com \\ Conflito de interesse: nada a declarar \\ Recebido em: 6/12/2012 \\ Aprovado em: 17/12/2012
}


were analyzed, the analysis of spirometric values showed no significant correlation with BMI. Therefore, similar to other authors' findings, no significant correlations were found between overweight/obesity and asthma using clinical, anthropometric, and spirometric parameters.

\section{References}

1. Lang JE. Obesity, nutrition, and asthma in children. Pediatr Allergy Immunol Pulmonol 2012;25:64-75.

2. No authors listed. The global asthma report 2011. Paris, France: The International Union Against Tuberculosis and Lung Diseases; 2011.

3. Kattan M, Kumar R, Bloomberg GR, Mitchell HE, Calatroni A, Gergen PJ et al. Asthma control, adiposity, and adipokines among inner-city adolescents. J Allergy Clin Immunol 2010;125:584-92.

4. Chen YC, Dong GH, Lin KC, Lee YL. Gender difference of childhood overweight and obesity in predicting the risk of incident asthma: a systematic review and meta-analysis. Obes Rev 2012. In press 2012.

5. Lang JE, Holbrook JT, Wise RA, Dixon AE, Teague WG, Wei CY et al. Obesity in children with poorly controlled asthma: Sex differences. Pediatr Pulmonol 2012. In press 2012.

6. Gibeon D, Batuwita R, Osmond M, Heaney LG, Brightling CE, Niven RM et al. Obesity associated severe asthma represents a distinct clinical phenotype Analysis of the British Thoracic Society Difficult Asthma Registry patient cohort according to body mass index. Chest 2012. In press 2012.
Thus, there is still much to investigate about how obesity can cause or aggravate asthma. It is clear that weight gain and obesity are particularly problematic in asthmatic patients and randomized controlled studies are needed to determine the best treatment approaches for asthma in obese patients.

7. Khan UI, Rastogi D, Isasi CR, Coupey SM. independent and synergistic associations of asthma and obesity with systemic inflammation in adolescents. J Asthm 2012. In press 2012.

8. Jensen ML, Wood LG, Gibson PG. Obesity and childhood asthma mechanisms and manifestations. Curr Opin Allergy Clin Immunol 2012;12:186-92.

9. Kilic H, Oguzulgen IK, Bakir F, Turktas H. Asthma in obese women: outcomes and factors involved. J Investig Allergol Clin Immunol 2011;21:290-6.

10. Lugogo NL, Bappanad D, Kraft M. Obesity, metabolic dysregulation and oxidative stress in asthma. Biochim Biophys Acta 2011;1810:1120-6.

11. Ferreira CA. Vitamina A, estresse oxidativo, inflamação e componentes da síndrome metabólica em crianças obesas com asma [tese de Mestrado]. São Paulo: Universidade Federal de São Paulo, Escola Paulista de Medicina; 2012.

12. Andrade LS, Araújo ACTB, Cauduro TM, Watanabe LA, Castro APBM, Jacob CMA et al. Obesidade e asma: associação ou epifenômeno? Rev Paul Pediatr 2013;31:138-44. 